Piotr Angiel

Polish Academy of Sciences

E-mail: pangiel@o2.pl

\title{
VARIABILITY OF TEXTURAL CHARACTERISTICS OF SANDUR DEPOSITS OF FLÁAJÖKULL AND FALLJÖKULL (SE ICELAND)
}

\begin{abstract}
Studies conducted on the sandurs of Fláajökull and Falljökull aimed at the reconstruction of the dynamics of braided rivers based on the grain size parameters of deposits. The goal of the project was to estimate the degree of deposit transformation and of changes of grain size characteristics as related to the length of transport in contemporary sandur rivers.
\end{abstract}

Key words: sandur, coarse clastic sediments, grain size parameters, Iceland.

\section{INTRODUCTION}

The goal of the paper was the determination of the variability of the textural characteristics of sandur deposits in profiles from the proximal zone in the distal direction on two sandurs Fláajökull and Falljökull which are currently being formed (SE Iceland, Fig. 1). The results of the study of the sediment variability of Fláajökull and Falljökull sandurs presented here constitute an extension of the earlier sedimentological studies conducted in Iceland by the research group of the Sedimentology Laboratory of the Faculty of Geography and Regional Studies, University of Warsaw, in the years 1998-1999 (Smolska et al. 1998 a, b). Research done in 2001 (Smolska et al. 2003; Smolska, Giriat 2004) has been expanded by the author by analyses of grain size parameters of sediments (Angiel 2003).

As part of the study sedimentological analyses of 29 sediment samples have been performed. Based on the results from sieve analyses, cumulative curves of grain size parameters on the probability scale have been drawn (Mycielska-Dowgiałło 1980); also, grain size parameters have been calculated based on Folk and Ward (1957). Sedimentological analyses of the coarsest fractions - an additional aspect of the study - allowed for achieving a broader view on the dynamics and mechanisms of sedimentation (Rutkowski 1995). 


\section{LOCATION OF AREAS UNDER INVESTIGATION}

The Fláajökull and Falljökull glaciers are parts of the Vatnajökull glacier (Fig. 1) situated on a Tertiary basaltic plateau, which at some places reaches the altitude $2000 \mathrm{~m}$ a.s.l. and whose tongues descend on the coastal plains. The plains constitute high sea terraces (up to $200 \mathrm{~m}$ a.s.l.) related to the isostatic and orogenetic lifting of the land during the Pleistocene and Early-Holocene recession of the continental ice-sheet. Rivers flowing out of the glaciers of the southern part of Vatnajökull shape this area by covering it with their alluvia. The braided system is one of the characteristic features of proglacial rivers, next to their straight-line segments cutting through the moraine ramparts. Sandur tracks formed on the forelands of Fláajökull and Falljökull glaciers are short. The sandur track of Fláajökull (formed by the Hólmsá River) is about $12 \mathrm{~km}$ long and flows directly to the Atlantic. The sandur track of Falljökull, on the other hand, (formed by the Virkisá River) is about $5.5 \mathrm{~km}$ long and joins that of the Skeidararjökull glacier (Fig. 1).

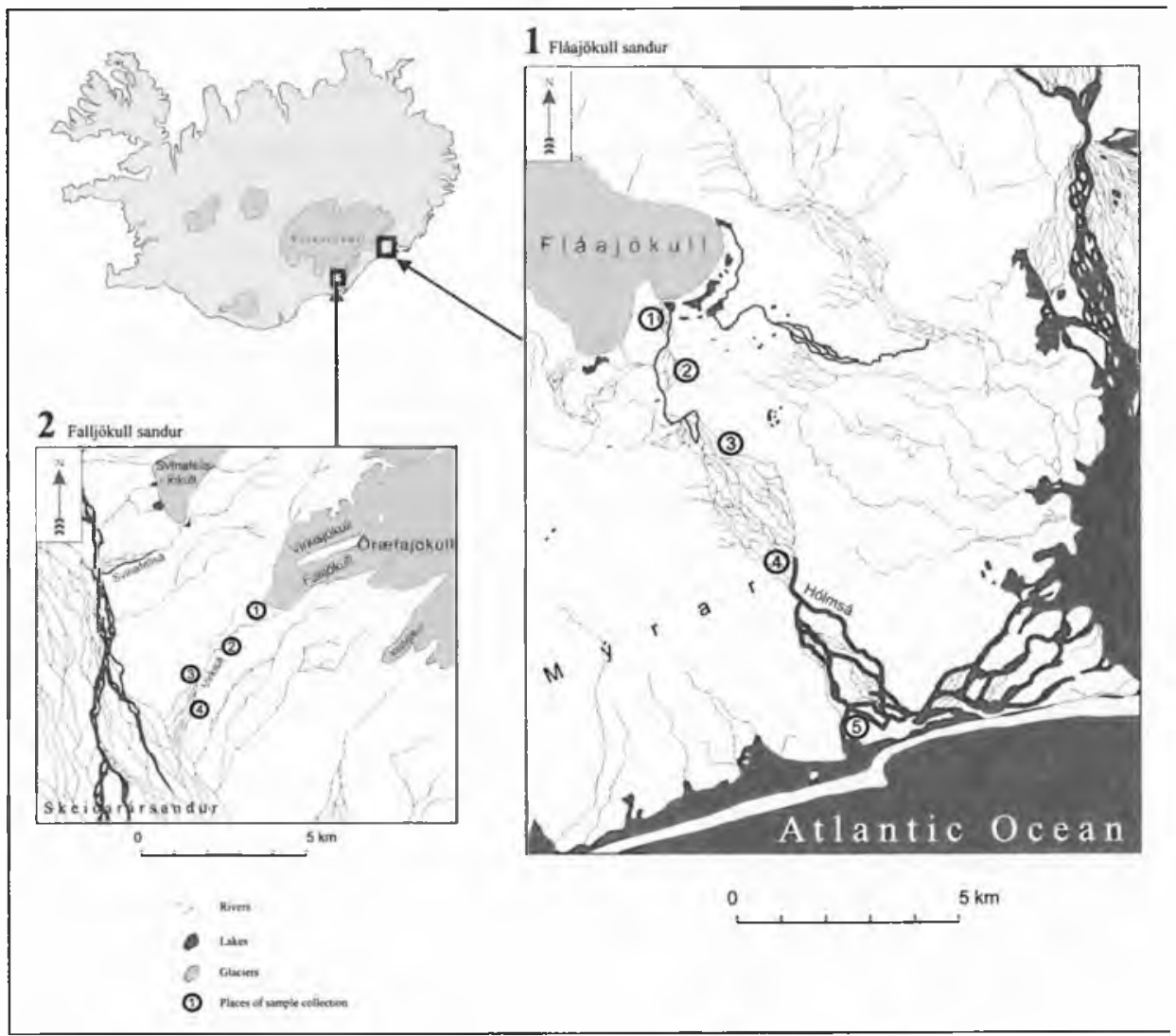

Fig. 1. Location of the area of research - sandurs of Fláajökull and Falljökull in SE Iceland 


\section{CHARACTERISTICS OF THE SANDUR DEPOSITS OF THE FLÁAJÖKULL AND FALLJÖKULL GLACIERS}

The purpose of the sediment analysis in profiles was to determine the difference between dynamics of individual sandur environments. To achieve this, profiles for both sandurs were being made, from moraines to the river mouth (to the Atlantic Ocean in the case of the Hólmsá River) or, in the case of Virkisá, to the confluence to the main river (Skeidarár). To characterise the river dynamics in individual stretches samples from middle part of the bars, side bars, bars behind the bars and from chutes within bars were taken. At each point of the profile one sample was analysed, taking into account the coarsest fractions contained in the sediment. (Additionally, moraine deposits were analysed this way.) The sample for this analysis was always taken from the middle part of the longitudinal bar.

The variability of the transport environment dynamics on both sandurs is large, which is evidenced by the simultaneous occurrence of coarse-grain and relatively fine-grain sediments in analysed deposits. Sedimentation of sandur deposits is very varied. It is formed by rises and falls, inscribed in sediments. Actually, in each point one could find coarse- and fine-grain deposits, often occurring in close proximity. This is an evidence of a large lateral facies variations in profiles perpendicular to the direction of flow.

The flow energy decreases as the distance from the glacier grows, which is marked by the occurrence of smaller fractions (from $\mathrm{Mz}=-5$ to $\mathrm{Mz}=-0.52$ ), and as the sediment sorting improves (from 2.03 to 1.53). Improvement of sorting and decrease of grain diameter is more visible in the profile of the Fláajökull sandur (Table 1, where samples from midle parts of bars of both sandurs are compared - in their sedimentological analyses the coarsest fractions were taken into account), which is related to the larger length of this sandur track.

Table 1.

Sedimentological coefficients of coarse-grain sediments of the middle parts of bars (taking into account in analysis the coarsest fractions contained in the sediment) in individual points of the profiles of Fláajökull and Falljökull sandurs (numbering of the profile points: see Fig. 2)

\begin{tabular}{|c|c|c|c|}
\hline Sample of & $\mathrm{Mz}$ & $\delta 1$ & Sk1 \\
\hline Fláa-moraine & -3.11 & 3.1 & 0.51 \\
\hline Flaa 1 & -5 & 2.03 & 0.37 \\
\hline Flaa 2 & -4.64 & 2.24 & 0.49 \\
\hline Flaa 3 & -3.47 & 2.29 & 0.48 \\
\hline Flaa 4 & -1.52 & 1.66 & 0.36 \\
\hline Flaa 5 & -0.52 & 1.53 & 0.31 \\
\hline
\end{tabular}

\begin{tabular}{|c|c|c|c|}
\hline Sample of & $\mathrm{Mz}$ & 81 & Sk1 \\
\hline Fall-moraine & -4.06 & 2.82 & 0.41 \\
\hline Fall 1 & -4.64 & 2.5 & 0.54 \\
\hline Fall 2 & -5.49 & 1.79 & 0.58 \\
\hline Fall 3 & -3.61 & 1.98 & 0.26 \\
\hline Fall 4 & -2.78 & 2.23 & 0.27 \\
\hline
\end{tabular}


Curves, both of frequency and cumulative show a large similarity of moraine sediments to sandur sediments in the proximal part of the sandur. Large accumulation dynamics of proglacial rivers in their upper course is demonstrated by the cumulative curves on the probability scale. The shape of the curves approaches straight lines. Such shape is interpreted as a sudden deposition of sediment transported in the sweeping phase - at the same time, sediment transported in dragging, saltation and suspension is accumulated. The maximal fractions occurring in the sediment had the diameter above $128 \mathrm{~mm}$. They were transported probably by dragging, although the size of the fraction indicates that these are erosion pavement sediments transported only during extreme high-water stages in sandur rivers. This fact may explain the bending of the cumulative curves in the segments below $-4 \mathrm{phi}$. If one interprets the cumulative curves as curves characterising various kinds of transport as described by G. S. Visher (Visher 1969), one should treat this segment as describing transport by saltation and the sediment above -4 phi (that is, below $16 \mathrm{~mm}$ ), as suspension, which seems rather unlikely.

\section{COMPARISON OF GRAIN SIZE PARAMETERS OF SEDIMENTS OF FLÁAJÖKULL AND FALLJÖKULL SANDURS}

In this paper three basic grain size parameters were calculated: standard deviation $\left(\delta_{1}\right)$, mean grain diameter $(\mathrm{Mz})$ and skewness $\left(\mathrm{Sk}_{1}\right)$, after the formulae by R. L. Folk and W. Ward (1957). Overall comparisons of standard deviation $\left(\delta_{1}\right)$ and mean grain diameter $(\mathrm{Mz})$ were made, as well as those of standard deviation $\left(\delta_{1}\right)$ and skewness $\left(\mathrm{Sk}_{1}\right)$.

Comparisons of the $\mathrm{Mz}$ coefficients and the standard deviation for both sandurs (Fig. 2) show a similarity. The arrangement of the point field, obtained when comparing the coefficients, exhibits a general tendency for sorting to deteriorate as the mean grain diameter increases. This is the most frequently encountered arrangement of the tendencies of the point fields, called the first system, and is characteristic for environments with varied dynamics and great variability of the sediment transporting force (MycielskaDowgiałło 1995). In the case of Fláajökull and Falljökull sandurs the variability of the medium dynamics is so large that the field system is very sharply inclined - the inclination of the tendency line for both sandurs is about 75 degrees.

In the case of comparisons of skewness and standard deviation (Fig. 3) there is a marked tendency for sorting to deteriorate as the predominance of fine-grain sediments over the fraction of maximal frequency grows. Sediments on both sandurs exhibit positive skewness (only one of 26 samples analysed had negative skewness). River sands, however, have usually negative skewness values (according to G. M. Friedman in Friedman 1961, 1967; after Mycielska-Dowgiałło 1980), which is related to the halting of the coarsest 

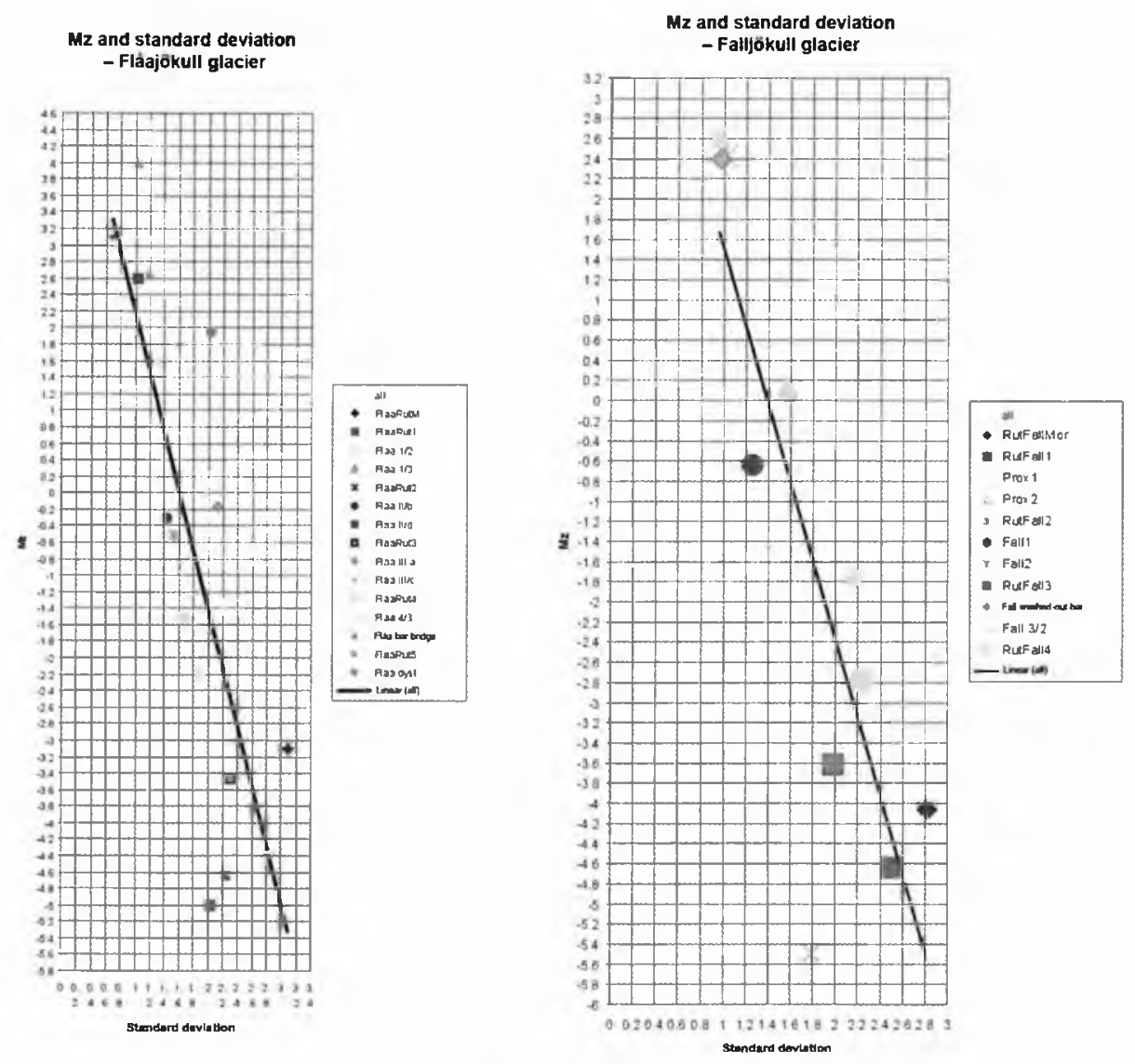

Fig. 2. Comparisons of parameters of mean grain diameter $(\mathrm{Mz})$ and standard deviation Fláajökull and Falljökull sandurs

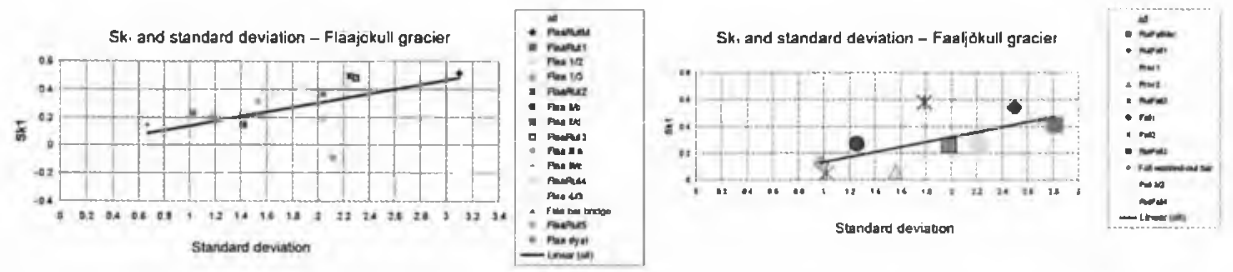

Fig. 3. Comparisons of skewness coefficients $\left(\mathrm{Sk}_{1}\right)$ and standard deviation - Fláajökull and Falljökull sandurs 
grains dragged at the bottom and to the immobilisation of grains transported by saltation between such coarse grains. In the case of both Iceland sandurs the key influence on the sediment character has the falling of the flood wave (surface sediments on bars uncovered after the flood, on surfaces of neighbouring bars and in chutes were analysed); as well as the fact that proglacial rivers carry the largest suspension and bottom load (Corbel 1959, 1964; after Mycielska-Dowgiałło 1980). In the case of Fláajökull and Falljökull sandurs the asymmetry of the frequency of grain size distribution, marked by a shift towards finer fractions, indicates a significant role of accumulation of sediments carried in suspension during the falling of flood wave.

\section{CONCLUSIONS}

The sediment analysis of the sandurs of Fláajökull and Falljökull demonstrates a large spatial differentiation of sediments in the profile from the front of the glacier to the mouth of the sandur river (to the Atlantic Ocean in the case of Flajajökull sandur) or to another larger sandur track (Falljökull sandur). On both areas a marked tendency for the mean grain diameter to decrease and for the sorting to improve in the distal direction exists. In the proximal part a large variability of sediments within the individual outwashes, where fine-grain deposits can occur together with gravel deposits, was demonstrated. This is related to the large variability of the snowmelt water flow in this stretch, both in the daily and the yearly cycle. In the distal part of each sandur, however, the variability of sediments within the individual elements of the riverbed was not equally marked.

The similarity of the dynamics of sandur sediment accumulation on both areas has been shown (similar shapes of curves of tendencies in comparisons of the mean grain diameter (Mz) and standard deviation) as well as differences. Particularly worth noting is the different progress of the field system tendencies in comparisons of skewness and standard deviation for the area of Iceland, related to the sudden sediment deposition during the fall of the flood water.

The author would like to thank dr Ewa Smolska, dr Dorota Giriat, Maja Walczak and Magdalena Zyszkowska as well as Grzegorz Osiński for assistance in field research.

\section{REFERENCES}

Angiel P., 2003, Cechy teksturalne osadów sandrów lodowców Fláajökull i Falljökull (SE Islandia) oraz sandru Wdy i ich znaczenie w rekonstrukcji środowisk sedymentacji [Texture characteristics of sediments of the Fláajökull and Falljökull glaciers sandurs (SE Iceland) and of the Wda River sandur and their importance for the reconstruction of sedi mentation environments; in Polish], master's thesis, Faculty of Geography and Regional Studies, Warsaw University. 
Folk R. L., W a r d W., 1957, Brazos River bar: A study in the significance of grain size parameters, d. Sed. Petrol. 27.

Glib ing M. R., R u st B. R., 1971, Evolution of a mud-rich meander belt in the Carboniferous Moraine Group, Nova Scotia, Canada, Can. Petrol. Geolog., 35, 24-33.

Mycielsk a - D ow g i a łł o E., 1980, Wstep do sedymentologii [Introduction to Sedimentology; in Polish], Wyższa Szkoła Pedagogiczna, Kielce.

Mycielska-Dowgiałło E., 1995, Wybrane cechy teksturalne osadów i ich wartość interpretacyjna [Selected texture characteristics of sedi ments and their interpretational value; in Polish], [in:] Badania osadów czwartorzędowych. Wybrane metody i interpretacja wyników [Study of Quaternary sediments. Selected Methods and Interpretation of Results; in Polish], E. Mycielska-Dowgiallo, J. Rutkowski (eds.), WGiSR UW, Warszawa.

Rutkowski J., 1995, Badania uziarnienia osadów gruboziarnistych [Study of grain size parameters of coarse grain sediments; in Polish], [in:] Badania osadów czwartorzędowych. Wybrane metody $i$ interpretacja wyników [Study of Quaternary sediments. Selected Methods and Interpretation of Results; in Polish], E. Mycielska-Dowgiałło, J. Rutkowski (eds.), WGiSR UW, Warszawa.

Smolska E., Szwarczewski P., Giriat D., Borkowski K., 1998a, Charakterystyka współczesnych gruboklastycznych osadów sandrowych Fláajökull i Falljökull w południowowschodniej Islandii [Characteristics of contemporary coarse clastic sandur sediments of Fláajökull and Fall jökull in southeastern Iceland; in Polish], [in:] Relief, Quaternary palaeogeography and changes of the polar environment, polar session II, Spitsbergen geographical expeditions, Wydawnictwo Uniwersytetu Marii Curie-Skłodowskiej, Lublin 1988, 143-149.

Smolska E., Szwarczewski P., Giriat D., Borkowski K., 1998b, Texture characterisation of the contemporary coarse clastic outwash sediments of Fláajökull and Falljökull in southeastern Iceland, Miscellanea Geographica 8, 55-65.

Smolska E., Szwarczewski P., Giriat D., Angiel P., 2003, Textural characteristics of the contemporary, coarse outwash sediments of Fláa jökull and Falljökull in SE Iceland, [in:] Ice Sheet Geomorphology - Past and Present Processes and Landforms, $34^{\text {th }}$ Binghampton Geomorphology Symposium, October 3-5, 2003, State University of New York at Binghampton, Binghampton, NY.

Visher G. S. 1969, Grain size distribution and depositional processes, J. Sed. Petrol. 39.

English translation: Matgorzata Mikulska 